\title{
A study to assess the knowledge regarding consanguineous marriages and its genetic effects among young adults with a view to develop an information guide sheet
}

\author{
Soujanya JP ${ }^{1}$, Amarnath GS ${ }^{2}$ \\ ${ }^{I}$ (Department of Nursing, BLDEA 'S Shri BM Patil institute of Nursing science, Bijapur/ Rajiv Gandhi university \\ of Health sciences, India) \\ ${ }^{2}$ (Department of Nursing, BLDEA'S Shri BM Patil institute of Nursing science, Bijapur/ Rajiv Gandhi university \\ of Health sciences, India)
}

\begin{abstract}
A study determines the knowledge regarding consanguineous marriages and its genetic effects among young adults. Tools used for assessment are Socio-demographic data of the young adults, structured questionnaire to assess the level of knowledge among young adults. Sample of the study comprised of 100 young adults in selected degree colleges, Tumkur.Scrutinizes revealed that more than half 61(61\%) of the young adults had scarce knowledge and only 39(39\%) hadsensible knowledge regarding Cognate marriages and its genetic effects. The paraphernalia used for the study weresensible and viable.
\end{abstract}

Keywords:Consanguineous Marriages, genetic, adults, knowledge, Socio-demographic.

\section{Introduction}

The study summarizes the knowledge about the consanguineous marriages in young adults. Knowledge regarding cognate marriages isinadequate, which is affecting the today's modern world due to lack of education and awareness about the marriage. Rituals of specific community and pseudo beliefs may be the major factors for the cognate marriages which affect genetically thereby promoting genetic disorders. To overcome the cognate marriages,study has been done which determines the percentage of awareness in the young adults by using socio-demographic and structured questionnaire as tools.

\section{Headings}

We are all connected to life. Every choice we make and every belief we hold exerts influence upon the whole of life. And we live with the consequences of our choice. As part of our biological health, this unique truth has physical expressions in honor, loyalty, family and group bonds. Probably this forms the basis of marriage, one of the most vital and powerful of our relationships. The human population has seen modern civilization and is still within family boundaries. One such familial-social bond in consanguineous marriage ${ }^{1}$.

Cousin marriage is a marriage between two cousins. Cousin marriage has existed in many cultures throughout history. In various jurisdictions and cultures, such marriages range from being considered ideal and actively encouraged, to being uncommon but still legal, to being seen as incest and legally prohibited. Such marriages are often highly stigmatized today in the West, but marriages between first and second cousins nevertheless account for over $10 \%$ of marriages worldwide. They are particularly common in the Middle East, where in some nations they account for over half of all marriages ${ }^{2}$.

Consanguinity ("con- (with/together) sanguine (blood) -ity (noun marker)") refers to the property of being from the same kinship as another person. In that respect, consanguinity is the quality of being descended from the same ancestor as another person ${ }^{3}$.

Consanguineous marriages occur in most populations, with varying percentages among all marriages. Populations in the Middle East, North Africa, South West Asia and South India where total consanguinity rates range between $20-50+\%$ of all marriages Populations in South America, China and Japan where consanguinity rates range between $1-10 \%$ of all marriages ${ }^{4}$.

In Indian population where consanguineous marriage is widely practiced, recessive/x-linked genetic disorders will continue to gain greater prominence in the overall spectrum of ill health. Developing an understanding of these changes will require a wide-ranging and multidisciplinary investigative approach for which community genetics is ideally suited to conditions in India ${ }^{5}$.

Genetic disease or genetic predisposition to disease is present in gametes before conception; therefore, theoretically it can be detected from that point on. If the capability exists for identifying a specific mutation, one can do so in gametes, in the zygote immediately after conception, in the early embryo, prenatally throughout pregnancy, in the newborn period, in childhood or adolescence, as part of reproductive planning in adulthood, or there after ${ }^{6}$. 


\section{Indentations And Equations}

The conceptual framework of the present study based on Backers Health Belief Model (1975). The sample of the study comprised of 100 unmarried young adults, age group between 20-25 years in selected degree colleges, Tumkur. Probability sampling technique was used to draw the sample for the research study. The tools developed and used for the data collection were Socio-demographic data of the young adults, structured questionnaire to assess the level of knowledge among young adults. Five experts validated the content of the tool and it was found to be reliable and feasible. The reliability of the tools was established by Spearman's Brown Prophecy Formula it was found reliable and the calculated value is 0.90 . The pilot study was conducted from 15.06.2010 to 21.06.2010 as a part of major study. Tool proved to be comprehensive, feasible and acceptable. The main study (data collection) was conducted from 1.07.2010 to 30.07.2010 after obtaining permission from Principal of the respected colleges. The investigator personally explained respondents the need, purpose and assuring them the confidentiality of their responses given. The data collected by structured interview schedule method and the collected data was analyzed. The data gathered were analyzed and interpreted according to the objectives. Descriptive statistics used were frequency, percentage, mean, percentage score, and standard deviation. Further inferential statistics like Chi-square test was used to test the hypothesis at $\mathrm{p}<0.05$ level of significance and the data obtained are presented in the graphical form.

\section{Results:}

The data findings have been organized and finalized according to plan for data analysis and results are presented under the followings.

- Description of demographic characters of young adults.

- Assess the knowledge of young adults regarding consanguineous marriages and its genetic effects.

- Association between knowledge scores of young adults and the selected demographic variables.

\section{Figures And Tables}

TABLE-1: Distribution of the subjects according to socio-demographic variables

\begin{tabular}{|c|c|c|c|}
\hline \multicolumn{2}{|l|}{ Demographic variables } & $\begin{array}{l}\text { No. of } \\
\text { subjects(n) }\end{array}$ & $\begin{array}{l}\text { Percentage } \\
\%\end{array}$ \\
\hline \multirow[t]{3}{*}{ Age } & $20-21$ years & 49 & 49.0 \\
\hline & $22-23$ years & 50 & 50.0 \\
\hline & $24-25$ years & 1 & 1.0 \\
\hline \multirow[t]{2}{*}{ Sex } & Male & 50 & 50.0 \\
\hline & Female & 50 & 50.0 \\
\hline \multirow[t]{2}{*}{ Place of residence } & Urban & 45 & 45.0 \\
\hline & Rural & 55 & 55.0 \\
\hline \multirow{3}{*}{$\begin{array}{l}\text { Educational status of } \\
\text { young adults. }\end{array}$} & B.A & 40 & 40.0 \\
\hline & B.Com & 34 & 34.0 \\
\hline & B.Sc & 26 & 26.0 \\
\hline \multirow{4}{*}{$\begin{array}{l}\text { Educational status of the } \\
\text { father }\end{array}$} & Illiterate & 17 & 17.0 \\
\hline & Primary school education & 16 & 16.0 \\
\hline & $\begin{array}{ll}\begin{array}{l}\text { Secondary } \\
\text { education }\end{array} & \text { school } \\
\end{array}$ & 31 & 31.0 \\
\hline & Graduate & 24 & 24.0 \\
\hline & Post graduate & 12 & 12.0 \\
\hline \multirow{5}{*}{$\begin{array}{l}\text { Educational status of the } \\
\text { mother }\end{array}$} & Illiterate & 30 & 30.0 \\
\hline & Primary school education & 26 & 26.0 \\
\hline & $\begin{array}{ll}\begin{array}{l}\text { Secondary } \\
\text { education }\end{array} & \text { school } \\
\end{array}$ & 39 & 39.0 \\
\hline & Graduate & 5 & 5.0 \\
\hline & Post graduate & 30 & 30.0 \\
\hline \multirow{2}{*}{$\begin{array}{l}\text { History of consanguineous } \\
\text { marriages }\end{array}$} & Yes & 55 & 55.0 \\
\hline & No & 45 & 45.0 \\
\hline
\end{tabular}


TABLE-2: Distribution of subjects according to level of knowledge

\begin{tabular}{|c|c|c|}
\hline Level of Knowledge & Frequency & Percentage \\
\hline Adequate & 0 & 0 \\
\hline $\begin{array}{c}\text { Moderately adequate } \\
\text { (50-75\% of score) }\end{array}$ & 39 & 39.0 \\
\hline $\begin{array}{c}\text { Inadequate } \\
(<50 \% \text { of score })\end{array}$ & 61 & 61.0 \\
\hline Total & 100 & 100 \\
\hline
\end{tabular}

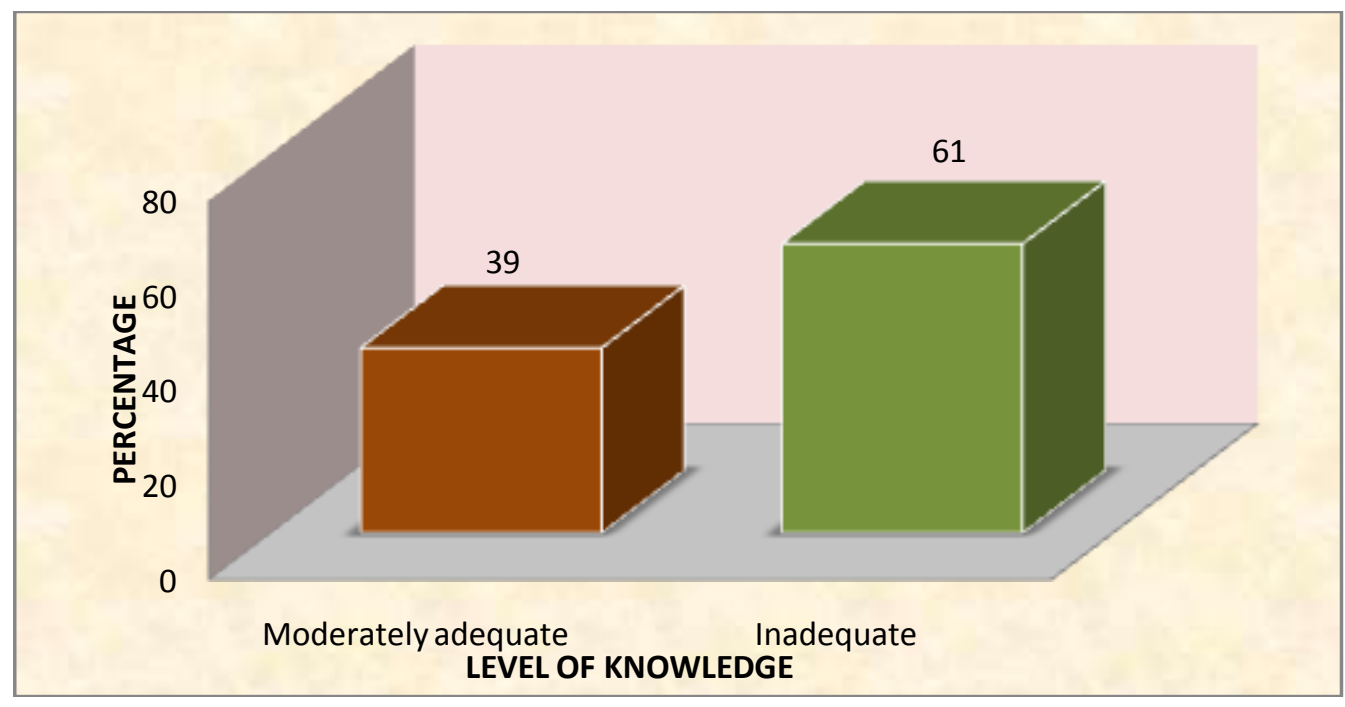

Fig-1: Distribution of subjects according to level of knowledge

TABLE 3: Knowledge score on different aspects of genetic effects of consanguineous marriages

\begin{tabular}{|c|l|l|l|l|}
\hline \multirow{2}{*}{ Area of Knowledge } & \multirow{2}{*}{$\begin{array}{c}\text { No of } \\
\text { items }\end{array}$} & \multicolumn{3}{|c|}{ Knowledge score } \\
\cline { 3 - 6 } & & $\begin{array}{l}\text { Mean } \\
\text { score }\end{array}$ & SD & Mean \% \\
\hline Consanguineous marriages & 10 & 3.85 & 0.88 & 38.5 \\
\hline Genetic disorders and genetic counseling & 22 & 8.28 & 1.38 & 37.64 \\
\hline
\end{tabular}

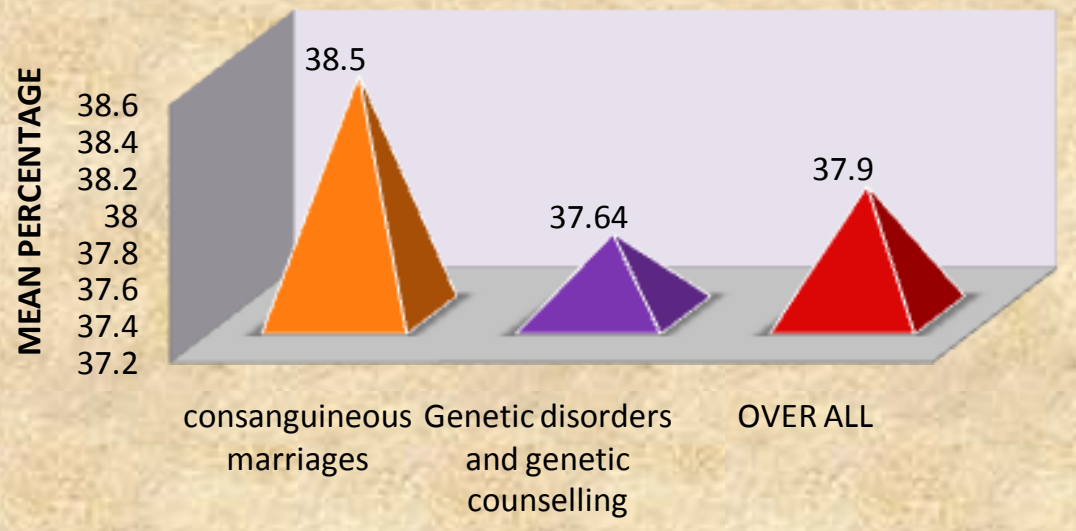

Fig-2: Knowledge score on different aspects on genetic effects of consanguineous marriages 
TABLE 4: Association between the knowledge score and selected demographic variables

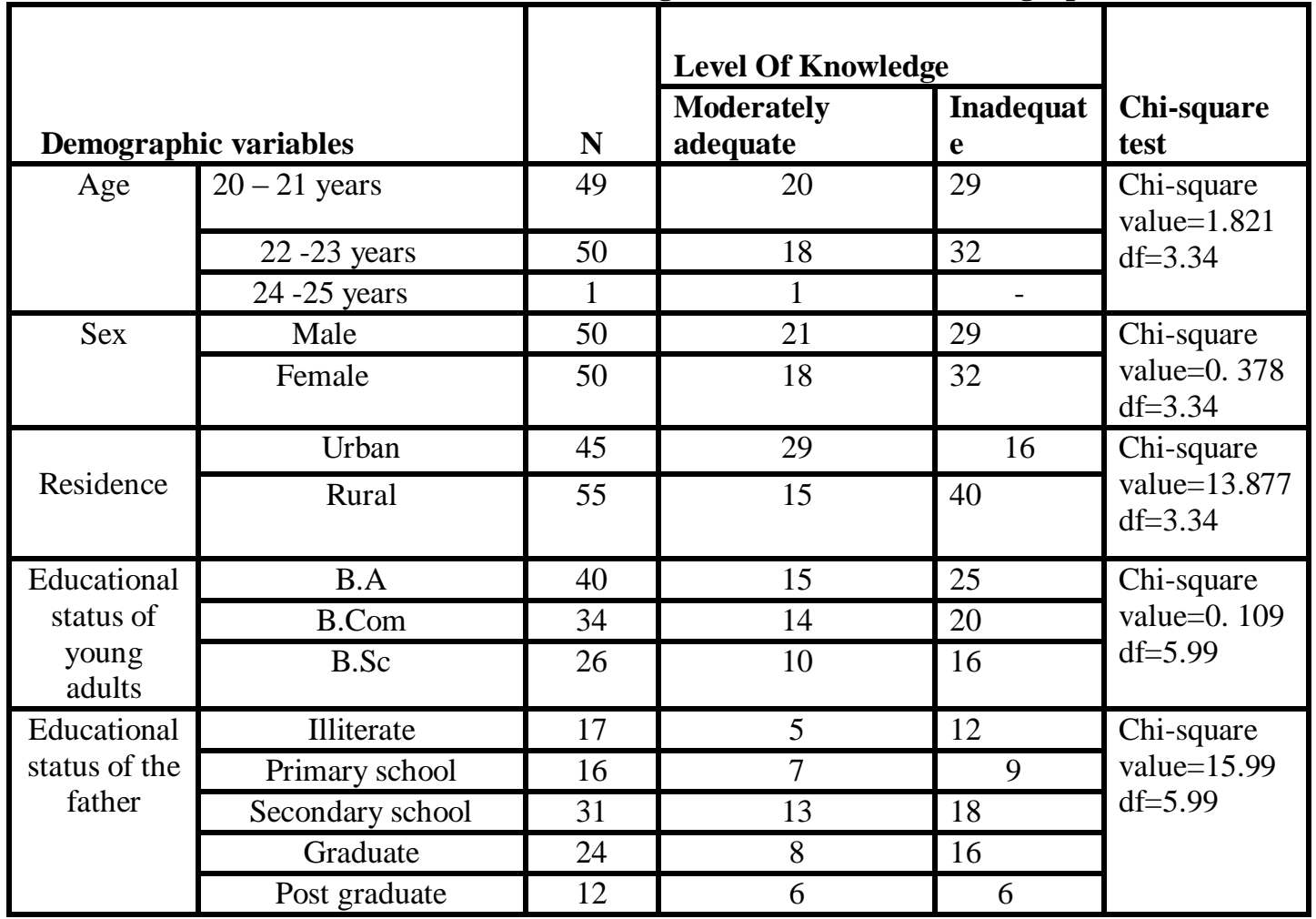

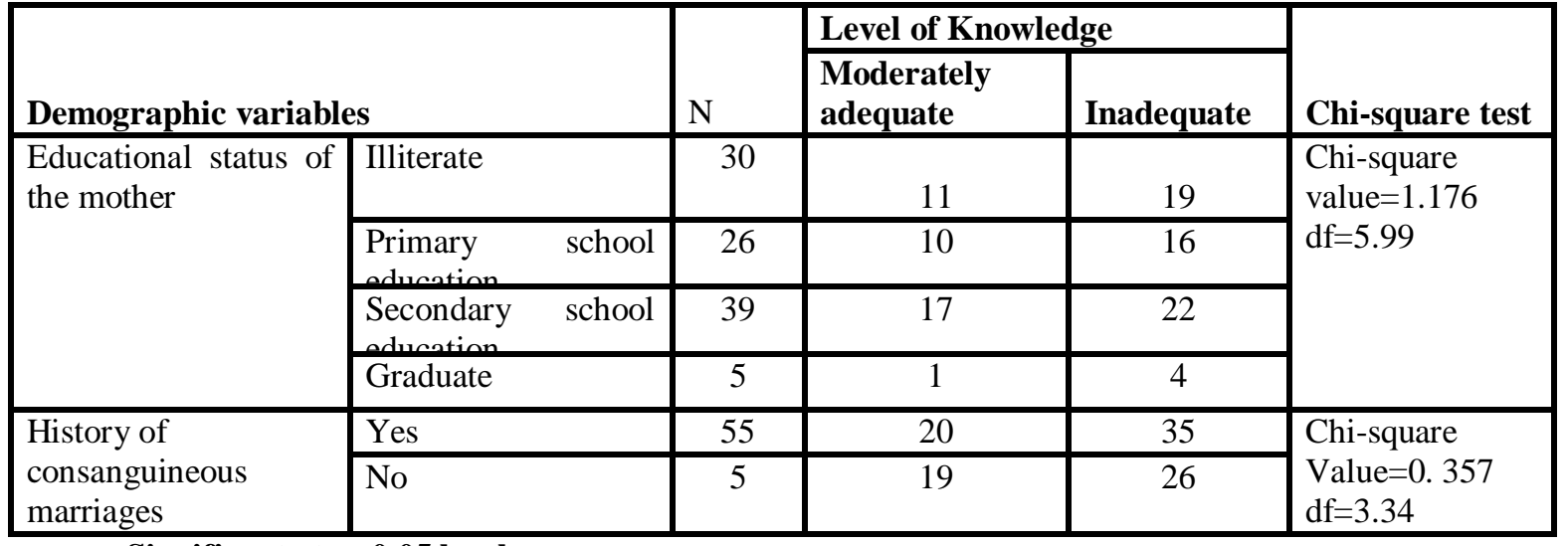

Significant at $\mathbf{p}<0.05$ level

From the above drawn results the mean percentage of knowledge on consanguineous marriages, genetic disorders and genetic counseling of young adults is $\mathbf{3 8 . 5 \%}$ and 37.64. Thestandard deviation is $\mathbf{3 . 8 5}$ and 8.28. The irrevocable results revealed that more than half $61(61 \%)$ of the young adults had inadequate knowledge and only 39(39\%) had moderate knowledge regarding Consanguineous marriages and its genetic effects. The association between knowledge score and selected socio-demographic variables of the age, sex, residence, educational status of young adults, educational status of father, educational status of mother and history of consanguineous marriages in the family. Of these variables the residence of young adults $\left(\chi^{2}=5.429\right.$, $\mathrm{df}=1)$ and educational status of father $\left(\chi^{2}=15.99, \mathrm{df}=4\right)$ were significant at $5 \%$ level i.e., $\mathrm{p}<0.05$. The rest of the socio-demographic variables were not significantly associated with knowledge.

\section{Conclusion}

Consanguineous/cognatemarriages and its innate effects have shown many health crisis, it has to be educated to human beings so that the crisis should be halted. Descriptive studies to assess the knowledge regarding consanguineous/cognate marriages and its genetic effects among young adults showed percentage of knowledge gained by them personally. The foremost findings of the study divulged that more than half $61(61 \%)$ of the young adults had scarce knowledge and only 39(39\%) had sensible knowledge regarding Cognate marriages. 


\section{References:}

[1] T.S. Sathyanarayana Rao, M.R. Asha, K. Sambumurthy, and K.S. Jagannatha Rao,Consaguinity: Still a challenge,Indian Journal of Psychiatry,51(1),July 2009, 3

[2] htpp//en.wikepidia.org/wiki/Cousin_marriage.

[3] R.F. Mueller, I.D. Young,Elements of Medical Genetics(Churchill Livingstone, 2001) 11th Edition: 100-245.

[4] MD. Prof. Hanan Hamamy. Consanguineous marriages in the Arab World, The Ambassadors online magazine, 6 (2), July 2003, 10810 .

[5] R.S.Balgir. Birth Control Necessary to Limit Family Size in Tribal Couples with Aberrant Heterosis of G-6-PD Deficiency and Sickle Cell Disorders in India: An Urgency of Creating Awareness and Imparting Genetic Counseling. Journal of association of physicians of India,58, June 2010, 357-62.

[6] Bernadette Modell, Aamra Darr. Genetic counseling and customary consanguineous marriage. Nature Reviews Genetics, 3, March 2000, 225-29. 